\title{
12. 突発性難聴の血管系機能不全説
}

○森満 保- 中島恒彦・平島直子・松元一郎 - 柴田浩一

林田邦彦・伊藤正博 - 中島元雄 - 渡辺 晋 (九大)

突発難聴といら病名は難聴が突発的に発症したといら 共通項でまとめられた疾患群の総称であり，将来的には 消滅すべきものである.

われわれは特発難聴の一例がアミドトリゾアート剂 （ウログラフィン）の注射により耳鳴と域值改善を示し たことから，突発難聴のアミドトリゾアート療法を創始 した. 1973年の 9 月より1975年 3 月までに本療法のみで 完治した症例 19 例, 著明回復例 4 例, 回復例 5 例, 無効 例21例が得られた。すなわちこの19カ月閒にアミドトリ ソ゚アート療法に極めて良く反応した症例23例を見出し た.これら症例の臨床的特徽を無効群と比較してみる と，回転性めまいを伴なわない，新鮮例（最長43日目） で，他に原因が推定されず，聴力損失は scacle out し ていないといら特徴がみられた。

こうした性質の突発難聴をアミドトリゾアート有效性 突発難㯖と仮称したいが，これが確かに独自なものであ るか否か検討してみた。

本症には自然治瘾例があるという。アミド剂は本来薬 理作用にそしいので, この自然治彩例の偶発的集中では ないかとも思われる。

過去に招ける九大教室の突難症例統計值と完全治療症 例率を比較したところ $\mathrm{X}^{2}=16.46$ 值 $1 \%$ で危險率で明 らかに有意であり，全治例を全て自然治缷例としても本 療法によるものと断定された，また治瘾曲線を九大例お よび Simmons 例と比較したところ, アミド有效群は平 7 均日で全治しているのに対し，従来治療法による全治 例は平均19日であり，本療法の独自性が支持される結果 であつた。

アミド有效性突発難聴が一つの独立した疾患として考 えることを許されるならば，その臨床像からその本態を 検討することができる.

まず回転性めまいを示さないことより，病変部位に前 庭迷路系が含まれていないこと，40日という長期間後に も完全に OdB まで全周波数城で回復することと, scale out 型でないことという事実は，蝸牛での障碍は不可逆
性になりやすい有毛細胞レベルの障碍ではないと思われ る,とするとその障碍の部位は血管条であり EPの低下に よるものとすれば実験病理学的にも充分に説明しらると いえる.すなわちアミド有効性突発難聴=血管条機能障 碍性難聴であると推測される，この突発難聴の血管条機 能障碍説は決して新らしいものでなく，血管条の Angionecrose 説 佳藤 (1957), 血管条機能障害による EP 低 下説切替方 (1967) がある。

現在アミド剤の内耳に括ける薬理作用を検討するとと もに種々の観点からのアプローチを試みつつある，特に 臨床的には Molecular biological approach として, ア ミド剤と姉妹関係にある他種トリヨードベンゼン化合物 で突発難聴の治療を試みつつある，構造式が僅かずつ異 なる化合物の治潦効果より，このトリヨードベンゼン化 合物のどのよらな構造が㔖発難聴に有効なのかを笑き止 めようといら試みである。現在イオタラメート戍, ヨー ダミド剤では数例であるがアミド剂と同じ治痖過程を示 した症例を経験し，また 2 例でアミド剤で回復が遷延し ている時にイオタラメート剤にかえ再び回復が促進され たのを経験した．こうした症例の積み重ねが本症の本態 解明に役立つ情報を呈供してくれるものと期待される. また聴覚電気生理学的にフローセミドと本剤の拮抗作用 があるのではないかと報告したが，更に実験をつみ重ね た結果もの少し険討すべき点があることが明らかとな りここの方面からの既報告に関しては結論を差し控えた w

最後に本説はアミド郕の臨床勃果に立㑢したものであ り，本療法が追試と批判をうけ，追認されなければ砂上 の楼閣となる、御追試を希望する。

追加 切替一郎 (自治医大). 本治療については現在 すべての専門医が注目しているところであるが，このこ とがきつかけとなつて突発難聴のおこつてくるメカニズ ムとくに血管条病態の解明が行われつつあることに深、 興味を抽ぼえる。 